нтам кваліфікованої медичної допомоги. У подальшому, спираючись на застосування інноваційного підходу до логістики у медичній сфері, 3'являється можливість створити контрольоване та регульоване середовище $з$ метою ефективного виконання різноманітних логістичних процесів у сфері охорони здоров'я i, таким чином, підвищувати певні показники регіонального розвитку.

\title{
Література:
}

1. Аранович Л.М., Рогоцкая Н.Д. Логистические подходы к ресурсному обеспечению ЛПУ. Бюллетень медицинских интернетконференциий. 2013. Т. 3. № 3. С. 617.

2. Смірнова В. Л., Панчишин Н. Я. Роль керівників охорони здоров'я в іiі реформуванні. Вісник соц. гігієни та орг. охорони здоров'я Украӥни. 2013. № 3. С. 26-28.

3. Рабаданова М.Р. Стратегическое планирование в системе управления учреждением здравоохранения. Apriori. серия: естественные и технические науки. 2013. № 1. С. 26.

DOI https://doi.org/10.30525/978-9934-588-81-5-2.11

\section{ПОРІВНЯЛЬНИЙ АНАЛІЗ СТРУКТУРИ ТА МІНЕРАЛЬНОГО СКЛАДУ КІСТКОВОЇ ТКАНИНИ НИЖНЬОЇ ЩЕЛЕПИ В НОРМІ, НА РІЗНИХ ТЕРМІНАХ ОПІОЇДНОГО ВПЛИВУ ТА ПІСЛЯ ТРАВМИ}

\author{
Масна 3. 3. \\ доктор медичних наук, професор, \\ завідувач кафедри оперативної хірургії з топографічною анатомією \\ Львівський національний медичний університет імені Данила Галицького \\ Согуйко P. P. \\ асистент кафедри оперативної хірургї̈ з топографічною анатомією \\ Львівський національний медичний університет імені Данила Галицького \\ Рудницька X. I. \\ кандидат медичних наук, \\ стариий викладач кафедри оперативної хірургії \\ з топографічною анатомією \\ Львівський національний медичний університет імені Данила Галищького
}




\section{Пальтов С. В. \\ кандидат медичних наук, дочент кафедри нормальної анатомії}

Львівський начіональний медичний університет імені Данила Галицького

Челпанова I. B.

кандидат медичних наук,

доиент кафедри гістології, иитології та ембріології

Львівський національний медичний університет імені Данила Галищького м. Львів, Украӥна

Злами кісток сьогодні посідають одне з чільних місць серед травматичних уражень. В стоматологічній практиці більше 50\% екстракцій зубів супроводжується руйнуванням кісткової тканини щелеп $[1,2]$. Перебіг постекстракційного періоду та відновлення кісткової тканини залежить від різних чинників $[1,2]$. Впродовж останніх років вживання населенням фармацевтичних препаратів, зокрема - препаратів знеболювальної дії, отримало знахне поширення [3]. Результати клінічних та експериментальних досліджень свідчать, що тривале вживання знеболювальних препаратів веде до структурних і функціональних змін органів та систем організму, розвитку медикаментозної або й наркотичної залежності $[3,4]$. Проте відомості про вплив опіоїдів на кісткову тканину в науковій медичній літературі сьогодні практично відсутні. Якість кісткової тканини залежить як від іï структури, так і від мінерального складу, порушення якого суттєво змінює фізичні властивості кістки [5]. Необхідною умовою адекватної діагностики відхилень показників якості та мінерального складу кісткової тканини від норми $є$ знання їх нормативних показників. Мета нашого дослідження - з'ясування закономірностей динаміки щільності та мінерального складу кісткової тканини нижньої щелепи на фоні тривалого вживання налбуфіну, після його відміни та після нанесення кісткоруйнуючої травми у інтактних тварин та на фоні опіоїдної залежності. Дослідження проведено на 100 білих безпородних статевозрілих щурах-самцях віком 3-3,5 місяці і масою 180-200 г. Тварини були розділені на 6 груп: 1- інтактні тварини, яким наносили кісткоруйнуючу травму (n 15), 2 - інтактні тварини, яким наносили кісткоруйнуючу травму 3 наступним лікуванням лінкоміцином (n 15), 3 - тварини, яким впродовж шести тижнів вводили налбуфін, моделюючи опіоїдну залежність (n 35), 4 - тварини 3 кісткоруйнуючою травмою, нанесеною після трьох тижнів вживання налбуфіну (n 15), 5 - тварини з кісткоруйнуючою травмою, нанесеною після трьох тижнів вживання нал50 
буфіну, та наступним лікуванням лінкоміцином (n 15), 6 - контрольна - інтактні тварини (n 5). Моделювання тривалого впливу опіоїду на організм здійснювали шляхом щоденного (1 раз на добу в однаковий проміжок часу) внутрішньом'язового введення наркотичного анальгетика налбуфіну за наступною схемою: I тиждень -8 мг/кг, II тиждень - 15 мг/кг, III тиждень - 20 мг/кг, IV тиждень - 25 мг/кг, V тиждень - 30 мг/кг, VI тиждень - 35 мг/кг. Травму моделювали шляхом порушення цілісності кісткової тканини (КТ) нижньої щелепи (НЩ) в ділянці великих кутніх зубів за допомогою стоматологічного бора . Операцію проводили під тіопенталовим наркозом. Лінкоміцин (30\% р-н) вводили внутрішньоочеревинно в дозуванні 25 мг/кг 1 раз на добу 6 днів після нанесення травми. Для визначення щільності КТ НЩ тварин усіх груп проведено вивчення 100 радіовізіограм досліджуваної ділянки. Радіовізіограми опрацьовано на апараті для дентальної радіовізіографії фірми Siemens з програмним забезпеченням Trophy Radiology, Одиниця виміру щільності тканин - умовна одиниця сірості (УОС). Щільність КТ НЩ визначали на рівні кута щелепи. Мінеральний склад КТ досліджували шляхом проведення атомноабсорбційного спектрального аналізу (ААCA) 100 фрагментів КТ НЩ щура. Досліджували вміст восьми мінеральних елементів $(\mathrm{Ca}, \mathrm{P}, \mathrm{Mg}$, $\mathrm{Na}, \mathrm{K}, \mathrm{Fe}, \mathrm{Sr}, \mathrm{Zn})$. Дослідження проводили на атомно-абсорбційному спектрофотометрі C-115, концентрацію елементів у зразках кісткової тканини вказували у мг/г. За даними радіовізіографічного дослідження встановлено, що щільність КТ НЩ щура в нормі становить $75,33+14,00$ УОС УОС. За даними ААСА КТ НЩ інтактного щура встановлено наявність у ії складі восьми мінеральних елементів в кількостях, можливих для визначення. Вміст Са становить $14,0067 \pm 0,2142 \mathrm{мг} / \Gamma, \mathrm{P}-11,5633 \pm 1,28056 \mathrm{мг} / \Gamma, \mathrm{Mg} 2,7867 \pm 0,5341 \mathrm{мг} / \Gamma$, $\mathrm{Na} 2,4333 \pm 0,3795$ мг $/ \Gamma, \mathrm{K} 2,9533 \pm 0,1120 \mathrm{мг} / \Gamma, \mathrm{Fe} 0,4500 \pm 0,1242 \mathrm{мг} / г, \mathrm{Sr}$

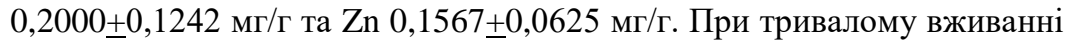
налбуфіну, впродовж перших двох тижнів щільність КТ НЩ поступово зростає, сягаючи до кінця другого тижня експерименту максимального значення $(85,67 \pm 29,86$ УОС), на третьому тижні різко знижується, повертаючись до норми (75,50+19,15 УОС), а впродовж наступних двох тижнів незначно зростає i мінімально змінюється до кінця

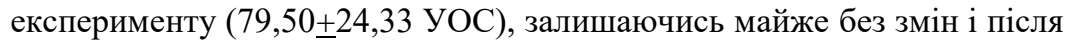
відміни препарату $(79,50 \pm 21,52$ УОС). На фоні шеститижневого вживання налбуфіну зростають абсолютні показники вмісту $\mathrm{Ca}(52,7500 \pm 1,4408 \mathrm{мг} / \Gamma), \quad \mathrm{P}(14,8466 \pm 0,1616 \mathrm{мг} / \Gamma), \quad \mathrm{Mg}(4,4367 \pm$ $0,2113 \mathrm{мг} / \Gamma), \mathrm{Na}(3,6600 \pm 0,8213 \mathrm{M} / \Gamma), \mathrm{Zn}(0,2600 \pm 0,0248 \mathrm{мг} / \Gamma)$ та 
$\mathrm{Fe}(1,2300 \pm 0,1383$ мг/г), залишаючись вище норми і після його відміни; знижується і залишається нижчою від норми і після відміни нал-

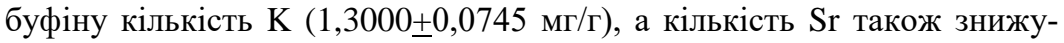
ється, але мінімально $(0,1900 \pm 0,1242$ мг/г), і після відміни налбуфіну має таке ж значення, як і у інтактних тварин. Встановлено виражену динаміку якості КТ НЩ впродовж трьох тижнів після нанесення кісткоруйнуючої травми тваринам без фонової патології та на фоні вживання налбуфіну і з наступною корекцією лінкоміцином. Впродовж трьох тижнів після нанесення кісткоруйнуючої травми інтактним тваринам щільність КТ НЩ становила 107,67 $\pm 27,56$ УОС, $152,00 \pm 20,85$ УОС та 99,50+30,06 УОС відповідно, після корекції лінкоміцином $92,33 \pm 28,55$ УОС, $104 \pm 28,21$ УОС $95,17 \pm 38,23$ УОС, після нанесення травми на фоні вживання налбуфіну 74,5+21,54 УОС, $86 \pm 35,25$ УОС, $133,5+58,51$ УОС та після корекції лінкоміцином $112,33 \pm 60,28$ УОС $, 91,67 \pm 21,03$ УОС, $86,17 \pm 23,39$ УОС. Таким чином, оптимальним $є$ відновлення якості КТ після кісткоруйнуючої травми у тварин, яким наносили травму на фоні вживання налбуфіну з наступною корекцією лінкоміцином, найбільш відмінною від нормативних показників є якість КТ у тварин, яким наносили травму на фоні вживання налбуфіну і не проводили корекції. Мінеральний склад КТ НЩ має виражену динаміку впродовж трьох тижнів після нанесення кісткоруйнуючої травми інтактним тваринам, тваринам, які вживали налбуфін, а також при корекції травми лінкоміцином. Через три тижні після травми, нанесеної інтактним тваринам, вищими від норми залишаються показники $\mathrm{Ca} \quad(41,7667 \pm 2,4842 \quad \mathrm{M \Gamma} / \Gamma), \quad \mathrm{P} \quad(14,30333 \pm$ 0,7205 мг/Г), $\mathrm{Na}(3,1467 \pm 0,2633$ мг/г), $\mathrm{Fe}(0,8 \pm 0,0497$ мг/Г) та Zn $(0,27 \pm$ 0,0248 мг/Г); нижчими від норми є показники $\mathrm{Mg}(2,58 \pm 0,0497$ мг/г) та K $(2,0967 \pm 0,1497$ мг/г), а кількість $\mathrm{Sr}$ повертається до нормального показника $(0,2 \pm 0,1242 \mathrm{мг} / \Gamma)$. Через три тижні після травми, нанесеної інтактним тваринам з наступним лікуванням лінкоміцином, вищою від норми залишалась кількість $\mathrm{Ca}(41,6933 \pm 2,2311$ мг/г), $\mathrm{P}(12,64667 \pm 0,1250 \mathrm{мг} / \Gamma), \mathrm{Na}(2,5367 \pm 0,2240 \mathrm{мг} / \Gamma), \mathrm{Fe}(1,0467 \pm 0,1250$ мг/г), Sr $(0,2133 \pm 0,1368$ мг/г) та Zn $(0,1733 \pm 0,0379$ мг/г); нижчою від норми - кількість $\mathrm{Mg}(2,08 \pm 0,0994$ мг/г) та К $(2,0467 \pm 0,1250$ мг/г). Через три тижні після травми, нанесеної на фоні вживання налбуфіну, вищими від норми $\epsilon$ показники $\mathrm{Ca} \quad(38,5267 \pm 2,3627 \quad$ мг/г), $\mathrm{Na}(2,55 \pm 0,1242 \mathrm{мг} / \Gamma), \mathrm{Fe}(0,67 \pm 0,0497 \mathrm{мг} / \Gamma)$ та $\mathrm{Zn}(0,3233 \pm 0,0379$ мг/г); нижчим від норми - показник K $(1,6633 \pm 0,1413$ мг/г), а показники $\mathrm{P}(11,52 \pm 1,1553 \mathrm{мг} / \Gamma), \mathrm{Mg}(2,7333 \pm 1,1326$ мг/Г) та $\mathrm{Sr}(0,2 \pm 0,1242 \mathrm{мг} / \Gamma)$ повертаються до норми. Через три тижні після травми, нанесеної на 
фоні вживання налбуфіну з наступним лікуванням лінкоміцином перевищують норму показники $\mathrm{Ca}(42,2633 \pm 2,2233 \quad \mathrm{M \Gamma} / \Gamma)$, $\mathrm{Na}(3,14 \pm 0,1490 \mathrm{мг} / \Gamma), \mathrm{Mg}(2,9633 \pm 0,1004 \mathrm{мг} / \Gamma), \mathrm{Fe}(0,71 \pm 0,1739 \mathrm{мг} / \Gamma)$ та Zn $(0,26 \pm 0,0248$ мг/г); нижчими від норми $\epsilon$ показники $\mathrm{P}(10,44333 \pm 0,1616$ мг/г), K $(2,08 \pm 0,0896$ мг/г) та $\operatorname{Sr}(0,18 \pm 0,1242$ мг/г).

Висновок. При тому, що якість КТ НЩ щура через три тижні після нанесення кісткоруйнуючої травми максимально наближається до норми у тварин, яким наносили травму на фоні вживання налбуфіну 3 наступною корекцією лінкоміцином, ії мінеральний склад, незалежно від того, наносили травму інтактній тварині чи на фоні тривалого вживання налбуфіну, а також незалежно від лікування лінкоміцином, потребує додаткової корекції.

\section{Література:}

1. Рибачук АВ, Мамонов РО, Маланчук ВО. Епідеміологія травматичних переломів нижньої щелепи в період з 2005 по 2014 р. за матеріалами клініки кафедри. Харківська хірургічна школа. 2016;1:117-122.

2. Kim TG, Chung KJ, Lee JH, Kim YH, Lee JH. Clinical Outcomes Between Atrophic and Nonatrophic Mandibular Fracture in Elderly Patients. J Craniofac Surg. 2018;29(8):e815-e818. doi: 10.1097/SCS.0000000000004863.

3. Brummett CM, Harbaugh C, Nalliah RP. Third Molar Extraction and Persistent Use of Opioids-Reply. JAMA. 2018;320(22):2377-2378. doi: 10.1001/jama.2018. 17203.

4. Hresko NI. Changes of colon angioarchitectonics under conditions of 2-4-week opioid effect in the experement Deutscher Wissenschaftsherold. German Science Herald. 2017;(5):43-48.

5. Tatara MR, Łuszczewska-Sierakowska I, Krupski W. Serum Concentration of Macro-, Micro-, and Trace Elements in Silver Fox (Vulpes vulpes) and Their Interrelationships with Morphometric, Densitometric, and Mechanical Properties of the Mandible. Biol Trace Elem Res. 2018;185(1):98-105. 